\title{
TWO ECOSPHERES, ONE LITERATURE: POST-1965 DEVELOPMENTS IN MALAY LITERATURE IN SINGAPORE AND MALAYSIA
}

\author{
Md. Salleh Yaapar \\ mdsalleh@usm.my
}

School of Humanities, Universiti Sains Malaysia, 11800 USM, Penang, Malaysia.

Tel.:+604-6532040

\begin{abstract}
Before 1965, Malay literature in Singapore and Malaysia was a single, shared entity. In fact, for a while, Singapore was one of the major centres of literary development, particularly through the endeavors of authors in Angkatan Sasterawan `50 (Asas 50) and friends in media and film. Singapore’s withdrawal from Malaysia in 1965 was an event that brought major changes, especially for Malay literature in Singapore. However, as this article hopes to show, although the split gave rise to far-reaching influences and two different sociopolitical ecospheres, activists of Malay language and literature in Singapore have persevered. Along with Malaysian activists and institutions, they continued to develop and enrich a shared Malay literature. For this purpose, the article will study historical developments in Singapore and Malaysia since 1965, particularly the diligent efforts, plans and activities to ensure that Malay literature continues to develop uninterrupted in Singapore. It also shows that the unity of the nations' literatures are not fragmented, but instead can continue to develop as one literature. Results of the observation show that early awareness, planning, strategy, positive action and determination have ultimately succeeded in nurturing and developing one Malay literature in Singapore and Malaysia that produces manifold results.
\end{abstract}

Keywords: Malay literature, Singapore, Malaysia, socio-political ecosphere, cooperation 
The Prime Minister declared the removal of the Southern Land from the Commonly Desired Land ...

Torn are the bonds of love, politics and history. 9 August 1965 is a mirror of sorrow ...

[Isa Kamari, Satu Bumi (One Earth), 1998]

\section{INTRODUCTION}

Before 1965, Malay literature in Malaysia and Singapore was one and the same entity. Malays in the Peninsula and in the island of Singapore considered it a shared literature. Authors too considered their efforts as a combined-Malay-literature. In fact, for some time, Singapore was the main centre of literary development. This was mainly due to the dynamic activities of Angkatan Sasterawan `50 (Asas 50), together with their friends from the media and film industries. At the time Singapore was not only the centre for language and literary activities, but also for media, film, music and culture in general. Thus, the withdrawal of Singapore from Malaysia on the 9th of August 1965 was an event that brought major and traumatic change especially in the development of Malay literature in Singapore.

This article will nevertheless show that although a split occured and there exists two different sosio-political ecospheres, activists of Malay literature and language in Singapore have persevered, and along with activists and institutions in Malaysia, continued to develop and uplift a shared Malay literature. For this purpose, this article will examine historical developments that occured in Singapore and Malaysia since 1965. In particular, it will focus on the determination, plans and activities carried out to ensure that Malay literature continues to develop uninterrupted in Singapore, and the unity of the literature of these two nations is not fragmented, but instead can continue to develop as one literature although they are no longer in the same socio-political ecosphere.

\section{ONE LITERATURE}

Throughout the Malay World, literature in the Malay language has traditionally been considered a single, shared entity. Even in modern times, until the early 
post-colonization eras of the West, there was not much change. Great works such as Sulalat al-Salatin, Hikayat Hang Tuah, Asrar al- 'Arifin, Bustan alSalatin, Tuhfat al-Nafis, Syair Perang Mengkassar and Hikayat Abdullah were claimed as common heritage and highly regarded, from Sumatera to Sulawesi. Oral poetry such as the pantun was spontaneously articulated by all levels of society and people of all ages, including children. Writers like Tun Sri Lanang, Hamzah Fansuri, Nuruddin al-Raniri, Raja Ali Haji, Abdul Samad al-Sumatrani, and Abdullah Munshi were the pride of all Malays wherever they were.

Generally, the titles and names of authors mentioned, and others like them, were recorded in books on the history of the literatures of Indonesia, Malaysia, Singapore, Brunei and Patani. This continued to this day. In fact, in Malaysia till the early 1980s, modern Indonesian writers like Hamka, Abdul Muis, Marah Roesli, Sutan Takdir Alisjahbana, Amir Hamzah, Khairil Anuar, Iwan Simatupang and Pramoedya Ananta Toer were included in the literature syllabus of secondary schools.

Like the previous macro scenario, in the context of pre-separation Malaysia and Singapore in 1965, Malay literature in both countries was a single, shared entity. In fact under the political union by the British colonizers known as Malaya, Singapore was the main centre for literary development for some time. This was due to the active role played by writers of Angkatan Sasterawan 50 (Asas 50) and their friends in the news writing and filming industries, which was, at the time, centred in Singapore. Asas 50 was established on 6 August 1950 against a backdrop of political turbulence. From 1950 to 1956 it was lead by Kamaluddin Muhammad (Keris Mas), Mohd Asraf Abdul Wahab (Asraf) and Usman Awang (Tongkat Warrant). Some members of Asas '50 were from the Peninsula, who had migrated to Singapore in search of work at newspaper and publishing companies and because of political oppression by the colonizers. On the other hand, several others like Masuri SN, Suratman Markasan, Cikgu Ariff Ahmad and Muhibbah Asmara came from Singapore but were educated in the Peninsula, at the Sultan Idris Teachers Training College in Tanjung Malim.

Asas 50 may be considered to have been "moored" at the Utusan Melayu organization. This was because its leaders worked there and works of members of this group were published in the organization's newspapers, Utusan Melayu and Utusan Zaman, as well as Mastika magazine (Ungku Maimunah Mohd.Tahir, 1998: 41-42). The voice of Asas 50 also resonated in other newspapers such as Suara Melayu and Melayu Raya and in magazines 
such as Hiburan, Mutiara, and Kencana. Film activists, especially P. Ramlee, were also affiliated with Asas 50, particularly through his film magazine, Majalah Bintang, which was led by Fatimah Murad, Asraf's wife.

Asas 50's name and influence was boosted by a debate between the group whose slogan was "Art for Society", led by Asraf who was affiliated with Utusan Melayu, and the Majalah Hiburan group whose slogan was "Art for Art", led by Hamzah Hussein (Hamzah). It was apparent that the philosophy of "Art for Society" gained more support, since it was more relevant to the social mood and upheaval in Malaya, as generally, sosio-economic progress and independence from the colonizers was desired. In 1954, Hamzah withdrew from Asas 50 to establish his own institution called Persatuan Angkatan Persuratan Melayu Baru, which evidently did not last long.

Members of Asas 50 strongly supported Kongres Bahasa dan Persuratan Melayu which had a major role in carving out a direction for the development of Malay language and literature in Malaya. For instance, Kongres Bahasa dan Persuratan Melayu III, was successfully held in Johor Bahru and Singapore on 16-21 September 1956 through the diligent efforts of Asas 50. It was at this Kongress that the name Balai Pustaka, established in Johor Bahru on 22 June 1956, was changed to Dewan Bahasa dan Pustaka, the name which has remained till now (Padilah Haji Ali, Jamaludin Mohd. Sulong and Arshad Rawian, 2012: 21). One of the early activities carried out by Dewan Bahasa dan Pustaka was the organization of a novel-writing competition in 1958. It was won by Salina (originally, Gerhana), a work of A. Samad Said, a member of Asas 50.

Generally, at the time, literary activities, works and the orientation of of Asas 50 members were not only followed and enjoyed by writers, activists and literary savants of the island of Singapore, but also in the Peninsula. Activists like Wijaya Mala (Abu Yazid Abidin), migrated to Singapore because of the movement. In fact, Asas 50 had a larger audience in the Peninsula, because the number of Malay residents was far greater compared to that in Singapore. Works by Asas 50 writers were also studied in universities, colleges and all secondary schools, and this was continued till some of them returned to the Peninsula either before or after the separation in 1965.

\section{TWO ECOSPHERES}

Persekutuan Tanah Melayu (or Malaya) obtained independence from colonial rule on 31 August 1957. On 16 September 1963, Singapore joined Malaya, along with Sarawak and north Borneo to form a new nation named Malaysia. 
However, Singapore's participation did not last long. On 9 August 1965 it was made independent of Malaysia, and a new nation called the Republic of Singapore was formed. Thus two socio-political ecospheres emerged at once, that is, Singapore and Malaysia (Singapore Ministry of Culture, 1965:3).

The event had a traumatic effect on the hearts and minds of Malays in general, and the Singaporean Malay community in particular, which found itself suddenly removed from its origins. In addition, it became a minority group, that is, approximately $13 \%$ of the total population of the Republic. The importance of their language too suddenly became reduced. Although it was considered a "National Language", it was only one of four official languages of the nation. Bahasa Melayu became an arrested and unimportant language, in comparison to the dominant English language of administration, education and employment. Moreover at the end of 1970 Malay-medium schools were closed down. The feeling of subjugation deepened with the weak socio-economic condition of Malays, portrayed in Mohd Latiff Mohd's poem, "Bangsaku di Hari Lahirku" (My race on my birthday) on 19 May 1974. The last line of the poem which means, "Di kiri duri, di kanan api" (Thorns to the left, flames to the right) encapsulates the chain of calamities that befell his community (http://hardiaziqin.blogspot.com/2011/10/ faktorfaktor-yangmempengaruhi.html).

Isa Kamari, an eminent contemporary Singaporean novelist evokes this poignant situation of two ecospheres almost 33 years later, as quoted in the epigram of this article. He writes in his first novel, Satu Bumi (One land) that:

Perdana Menteri mengisytiharkan kelontaran Nusa Selatan dari Nusa Secita... Perdana Menteri menangis ketika itu...Terputuslah tebuni yang menalikan ikatan kasih, siasah dan sejarah. 9 Ogos adalah kaca duka...

The Prime Minister declared the removal of the Southern Land from the Commonly Desired Land ... The Prime Minister wept at that time... Torn are the bonds of love, politics and history. 9 August 1965 is a mirror of sorrow ...

(Isa Kamari, 1998:168)

The tearing of "bonds", and all other matters highlighted in the foregoing paragraphs consequently gave rise to the pressing question of the status and future of Malay literature in the Republic of Singapore. The question requires attention primarly because of the reduced importance and marginalization of the Malay language as explained. In comparison to Malay literature, literature in English was set to fly high in Singapore. Additionally, political separation 
from the Peninsula in the north had reduced the audience of Malay literature in Singapore. In the context of writing, a majority of well-known Asas 50 writers were, at that stage, aged. At the same time, many eminent writers like Kamaluddin Muhammad, Usman Awang, A.Samad Said and Asraf had returned to the Peninsula after 1957. In this context, it is only the secondgeneration or new writers who remained to continue the tradition of Malay literature in Singapore. Evidently, they were to shoulder the burden of the fate and future of Malay literature.

In the 1960s there was a group of new authors. Among the more important ones were Mohammed Latiff Mohammed, Djamal Tukimin, Suraidi Sipan, Megadona, Eunosasah, Mohd Taha Jamil, Yatiman Yusof, Nor Yusman Abdul Majid, A Hamid Ismail, Ajaki, F.R Bahamid and Samsidah Suleiman. However the harvest of publications in this decade was very small. Masuri SN voiced his concern over the fact that between 1965 and 1976, only six novels were published, and that too by veteran writers like Harun Aminurrashid, Mahmud Ahmad and Mas. The total number of short stories and poems too was very small (Mohamed Pitchay Gani Bin Mohamed Abdul Aziz, 2005:21).

\section{MISFORTUNES AND MOVES}

As a result of the alarming situation that resulted from the sudden emergence of two socio-political ecospheres, activists of language, literature and culture in Singapore took prompt, introspective steps. Among others, the annual event of the Writers Workshop organized by Asas 50 in 1970.

Consequently, the years that followed witnessed the emergence of new writers along with the establishment of writers' groups and literary fans. Among them was the poetry group, Grup Gelorasa established in 1971 with savants like Djamal Tukimin, MIA and Ajaki. The group was well-known for its series of councils called "Dari Tambak ke Tambak" (From dam to dam). Furthermore, in 1972, Mohamed Latiff Mohamed, Mila Karmila, Budi Hartini and several other writers founded the very active Pertubuhan Aktivis Sastera Singapura (PASS). At the same time, Asas 50 enhanced its role in keeping with the times. On 4 and 5 August 1973, it launched a Literary Village for the first time since the separation from Malaysia. The aim of this is evident in its declared objective, that is, "To review the development of Literature in Malay and its sustenence and enrichment in a multi-ethnic society, particularly in Singapore." About 150 established young writers, including several from Brunei and Malaysia, attended the Village (Mohamed Pitchay Gani Bin Mohamed Abdul Aziz, 2005:23). 
Subsequently in 1978 Asas 50 launched a novel-writing competition with the objective of overcoming the problem of scarcity of novels which Masuri SN had voiced. Furthermore on 24 June 1979, Asas 50 organized a "Gathering of Singaporean Writers". Its goal was to reassess the status and achievement of current Singaporean Malay literature. In the gathering a great deal of scrutiny and opinion was forwarded on the status of short stories, novels and poetry, for on-going action. Suratman Markasan, for example, said, "... a lot of the poetry lacks direction. Authors do not have clear goals, and many are ill-informed, with insufficient awareness of creative devices" (Sumadi Sarkawi, 1979:5).

It was in these ways that early awareness, introspection and efforts at constant assessement produced the directions, action plans and strategies for the progress of Malay literature in Singapore. This was supported by the planning, efforts and activities held at a regional level involving Malaysia, Indonesia and Brunei.

\section{DEVELOPMENTS IN SINGAPORE}

The result of early awareness, introspection and continuous assessment implemented in Singapore may be observed from several aspects, as well as chronologically, as follows.

With regard to development, apart from Asas 50, Grup Gelorasa and PASS which have been mentioned, other organizations sprouted since the 1970s such as Sudut Penulisan Perpustakaan Toa Payoh (end of 70's), Jejak Kembara (1978), KUPUJA (youth wing of Asas 50, 1984), Kumpulan Angkatan Muda Sastera (KAMUS, 1989), Nadwah Sastera (1990) and Kelab Coretan Remaja (KCR, 1994), (Mohamed Pitchay Gani Mohamed Abdul Aziz, 2005: 45). Kembara was unique in that it was a group within the National University of Singapore, whose members included academicians like Dr. Hadijah Rahmat, Rasiah Halil and Normala Mustafa.

Various activities were organized, including "Dari Tambak ke Tambak" by Grup Gelorasa, as mentioned. At the same time, in 1977 Asas 50 pioneered a new activity at the regional level which they called "Pertemuan Sasterawan Nusantara" (A Gathering of the literati of the Archipelago). In accordance with its name, this great event was a platform for a major gathering of authors from Singapore, Malaysia, Indonesia and Brunei. Currently, it is a prestigious biannual event of the Malay world, greatly anticipated by many authors and scholars of literature. 
Efforts involving the above movements and activities were augmented by attempts at promoting recognition through offering literary awards like in Malaysia. Thus, in 1975, at the suggestion of Asas 50, Jawatankuasa Bersama Hadiah Sastera (JBHS), a joint committee on literary awards was established. It was this Committee (with several changes of name) which was responsible for the successful establishment of the first Majlis Hadiah Sastera (Literary Award Council on 12 October 1975. Following this, it was held once every two years until the sixth award in 1986. The Hadiah Sastera award had a high and very positive impact. It motivated writers to make the effort to produce more high-quality works. As a result, towards the end of the 1970s and 1980s, there was an increase in the number of quality works. As Mohamed Pitchay Gani Mohamed Abdul Aziz notes,

Zaman 80'an merupakan kemuncak kepada perkembangan sastera kerana tempias daripada kegiatan Hadiah Sastera di Singapura yang bermula pada tahun 1975. Para penulis muda semakin terangsang untuk bergerak dalam dunia penulisan melalui pertubuhan. Maka lahir pula Kumpulan Pemuisi Remaja (KUPUJA) iaitu cabang belia daripada ASAS 50. Ini diikuti oleh tertubuhnya Kumpulan Angkatan Muda Sastera (KAMUS) yang dianggotai Mustapha Mohamed, Hamidah Mohamed, Ahmad Md Tahir dan Khalid Lani. (2005: 24)

[The 80s era was the climax of the development of Malay literature as a side-effect of the Hadiah Sastera award in Singapore, which began in 1975. Young writers were increasingly motivated to be active through affiliation to organisations. Thus, Kumpulan Pemuisi Remaja (KUPUJA), the youth wing of Asas 50 was created. This was followed by the founding of Kumpulan Angkatan Muda Sastera (KAMUS) whose members included Mustapha Mohamed, Hamidah Mohamed, Ahmad Md Tahir and Khalid Lani (2005: 24)]

Other than the Hadiah Sastera awards from within the nations, Masuri SN and Suratman Markasan who are established Singaporean authors, obtained the S.E.A Write Award, bestowed by the King of Thailand in 1980 and 1989 respectively.

Further to developments in the 1980s, activities in the 1990s to the present era were being increasingly animated. Activities and the number of quality works were increasing. The Hadiah Sastera award which ceased for six years was reactivated by the Majlis Bahasa Melayu Singapura (MBMS). Rebranded as Anugerah Persuratan, it began bestowing awards in 1993. This event was held every alternate year along with Sambutan Bulan 
Bahasa (Language commemoration month). Anugerah Persuratan covers three categories, Anugerah Tun Seri Lanang, Anumerta Tun Seri Lanang and Anugerah Harapan, with Anugerah Tun Seri Lanang being the highest. Winners of Anugerah Tun Seri Lanang include pendeta (literary savants) Dr Haji Muhammad Ariff Ahmad (1993), the late Dr Masuri SN (1995), Abdul Ghani Hamid (1997), Suratman Markasan (1999) and the most recent, Assoc Prof Dr Hadijah Rahmat (2011). According to Mohamed Pitchay Gani Mohamed Abdul Aziz's records,

Dunia penerbitan Melayu juga semakin rancak khususnya dalam karyakarya kreatif. Jumlah karya bukan-fiksyen juga semakin meningkat. Bagi tahun 2003 dan 2004 terdapat anggaran 40 judul bagi karya kreatif dan 10 judul bagi bukan-kreatif. MBMS sendiri menghasilkan 10 judul.Terdapat juga peningkatan dalam jumlah dan kekerapan jurnal serta majalah bagi bahasa dan persuratan yang diterbitkan.(2005: 33)

[The Malay publishing world also became more active, especially in creative works. The total number of non-fiction works too increased. In 2003 and 2004, there were approximately 40 titles of creative works and 10 of nonfiction. MBMS alone produced 10 titles. There was also an increase in the number and frequency of journals and magazines of language and letters published. (2005: 33)]

An interesting development was the ability of Singaporean activists of Malay literature to direct the attention of (non-Malay) government and private institutions to Malay literature. This is evidenced by the commitment of several public and private institutions such as the National Arts Council, National Library Board, National University of Singapore, Nanyang Institute of Education of Nanyang Technological University and the Ministry of Education, in their efforts to develop Malay language and literature. The National Arts Council, for example, frequently assisted writers and culturalists in producing new works. These efforts were implemented with Cultural Medallion (Medalion Budaya) grants to the value of 50 thousand dollars each. The National Library Board was want to help writers and associations in the publication of books. Among others, it helped Asas 50 to publish Leksikon: Direktori Penulis Melayu Singapura Pasca 1965, a work by Mohamed Pitchay Gani Mohamed Abdul Aziz in 2005. This is the only directory of its kind that is comprehensive and authoritative on post-1965 Singaporean Malay writers. 
In language and literature education, Nanyang Institute of Education at Nanyang University of Technology has, since 2001, introduced a programme of Masters in Malay Language and Literature, which is recognized by the Singaporean Ministry of Education. Nanyang University of Technology is also known for its NIE Campus Townsville programme which hones the skills of young writers.

\section{DEVELOPMENTS IN MALAYSIA}

This section will discuss several Malaysian initiatives, activities and developments in language and literature which is closely connected, or has implications, on the status and development of Malay language and literature in Singapore.

Around the time of the Independence of Malaya in 1957, many Asas 50 authors who were from the Peninsula including Keris Mas, Usman Awang, Salleh Daud, A.Samad Said, Asraf and Awam Al-Sarkam returned home, specifically to Kuala Lumpur. Most lived in Petaling Jaya, close to University of Malaya, which moved there from Singapore in 1959. Here, authors like Mohd. Taib Osman, Ismail Hussein, Agus Salim, Syed Husin Ali, Kassim Ahmad often discussed the status and development of Malay language and literature with lecturers and students of the University. These discussions eventually gave rise to the idea of establishing Persatuan Penulis Nasional (PENA), which was similar to Asas 50. PENA was established at University of Malaya, Kuala Lumpur on 12 February 1961. It became an important platform to unite and harness the strength of authors and literary fans of the nation, particularly around the capital city. Nearly 10 years later, a conference of representatives of writers' associations was held at Dewan Bahasa dan Pustaka, on 23 October 1970. The Conference agreed to establish a combined body called Gabungan Persatuan Penulis Nasional Malaysia (GAPENA). PENA joined in this combined body. Among the objectives of this body was to "Unite all the people of this nation through a sole national language, that is, Bahasa Melayu", and to "Make an attempt to develop the Malay language, literature and culture at national and international levels." The presence of this body animated activities and efforts towards the development of language and literature in Malaysia.

It is necessary at this point to note that Dewan Bahasa dan Pustaka is the sole governmental institution in Malaysia with the responsibility of preserving, perpetuating and developing Malay language and letters. Ever since it was 
in Johor Bahru, up to the present day in Kuala Lumpur, Dewan Bahasa dan Pustaka has made major contributions in the development of language and literature not only in Malaysia, but also in Singapore. Currently, Dewan Bahasa dan Pustaka is under the jurisdiction of the Ministry of Education and has branches in Sarawak, Sabah and regional offices in Penang (North), Kota Bahru (East), Kuala Lumpur (Centre) and Melaka (South) (Padilah Haji Ali, Jamaludin Mohd. Sulong dan Arshad Rawian, 2012). In addition to preserving the language and providing service in matters related to language and the publication of books, magazines and journals, Dewan Bahasa dan Pustaka has provided a great deal of assistance to associations such as the combined bodies of GAPENA, and institutions of higher learning in language and literature activities. In the field of publication, it has published works of Singaporean writers widely. This includes contemporary authors like Hadijah Rahmat and Rasiah Halil. Among Hadijah Rahmat's works published by Dewan Bahasa dan Pustaka are Di Tengah Alam (1998) and Mengukir

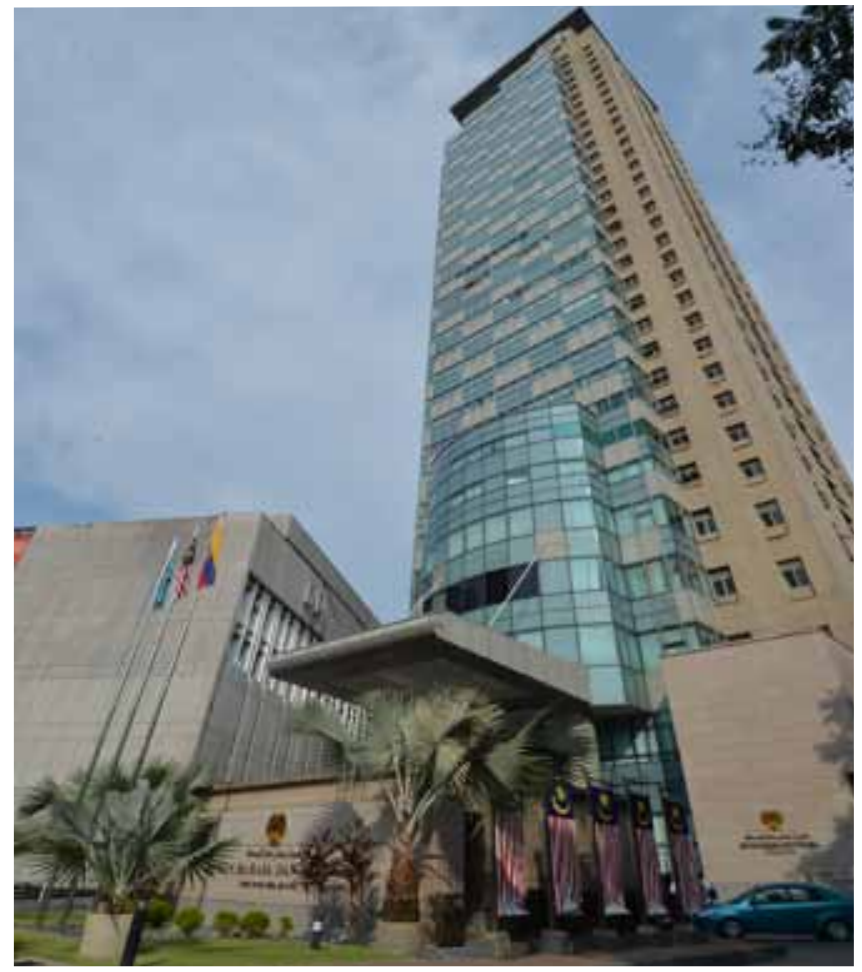

Figure 1 Dewan bahasa dan Pustaka, Kuala Lumpur. 
Air di Pesisir: Sastera Melayu/Indonesia dalam Arus Jagat (2005). Rasiah Halil's works are Orang Luar (1991) and Nyanyian Si Anak Dagang (2013).

In efforts to enhance the status of Malay literature, Dewan Bahasa dan Pustaka recognizes and rewards outstanding authors with prizes and awards. The earliest was Hadiah Karya Sastera, the name and concept of which is similar to the Hadiah Sastera introduced in Singapore in 1975. Hadiah Karya Sastera was introduced as an annual event from 1971 to 1976. It was successful at the time in drawing attention to young, highly talented writers such as Latiff Mohidin, Anwar Ridhwan, Zakaria Ali, Fatimah Busu, Jaafar H.S., Zurinah Hassan, Zaihasra, Azmah Nordin, Zahari Affandi, T. Alias Taib and Lim Swee Tin. The award ceased for five years. Later on, from 1982/1983 it re-emerged as Hadiah Sastera Malaysia, with biannual evaluations. From 1996/1997 to the present time, the status of this award has been upgraded and rebranded as Hadiah Sastera Perdana Malaysia (HSPM).

The responsibility of awarding the highest national recognition of Malaysian authors has long been with Dewan Bahasa dan Pustaka. Anugerah Sastera Negara awards recognition based on distinction. Recipients of this distinguished award not only obtain a monetary reward and health facilities but also the title of Sasterawan Negara (National Laureate). The award was first given in 1981 on a similar concept as Anugerah Tun Sri Lanang which started in 1993. So far, 12 prominent figures of Malay literature in Malaysia have received this prestigious award, including four figures who were active in Singapore, that is, Keris Mas (Kamaludin Muhamad), Usman Awang, A. Samad Said and Abdullah Hussain.

Other than the abovementioned responsibilities, Dewan Bahasa dan Pustaka is also responsible as a strong catalyst of Majlis Sastera Asia Tenggara (MASTERA), a council for the planning and review of the regional development of literature in the Malay/Indonesian languages. It was officially established on 26 August 1996 by three founding nations, that is, Brunei Darussalam, Indonesia and Malaysia. According to its foundation charter, it is a regional council representing the board of rulers of each participating nation. Participation comprises three groups, the founding nations, member nations and observer nations. The officiating ceremony was witnessed by representatives from Singapore, the Phillipines, Thailand and Vietnam. MASTERA's formal activities encompass Seminar Sastera MASTERA, Siri Kuliah Kesusasteraan Bandingan, Sanggar Teater Serantau MASTERA, Hadiah Sastera MASTERA, the publication of Jurnal PANGSURA, Siri Kuliah Kesusasteraan Bandingan publications, and publishing MASTERA books.

After 16 years as an observer, Singapore eventually agreed to join as a 
member nation and was unanimously accepted. The entry of Singapore as the fourth member was announced at the official opening ceremony of Sidang Ke-18 MASTERA (18th MASTERA Conference) held at Dewan Bahasa dan Pustaka, Kuala Lumpur on 18 October 2012 (see, "Singapura anggota terbaru MASTERA", 2012). At the ceremony, the Director of Dewan Bahasa dan Pustaka affirmed confidence that the entry would greatly enhance the status of Malay literature in Singapore. In fact prior to becoming a member nation, on 28 September 2004, Singapore was invited to engage in efforts for the success of the Kuliah Kesusasteraan Bandingan MASTERA 2004 programme. Subsequently in 2005, Associate Professor Dr. Hadijah Rahmat of Nanyang Technological University was honoured with delivering a lecture in the member countries. The text of her lecture, entitled, "Mengukir Air di Pesisir: Sastera Melayu/Indonesia dalam Arus Jagat" was published by Dewan Bahasa dan Pustaka, Kuala Lumpur (Hadijah Rahmat, 2005). In November 2013 Dr. Azhar Ibrahim Alwee of the National University of

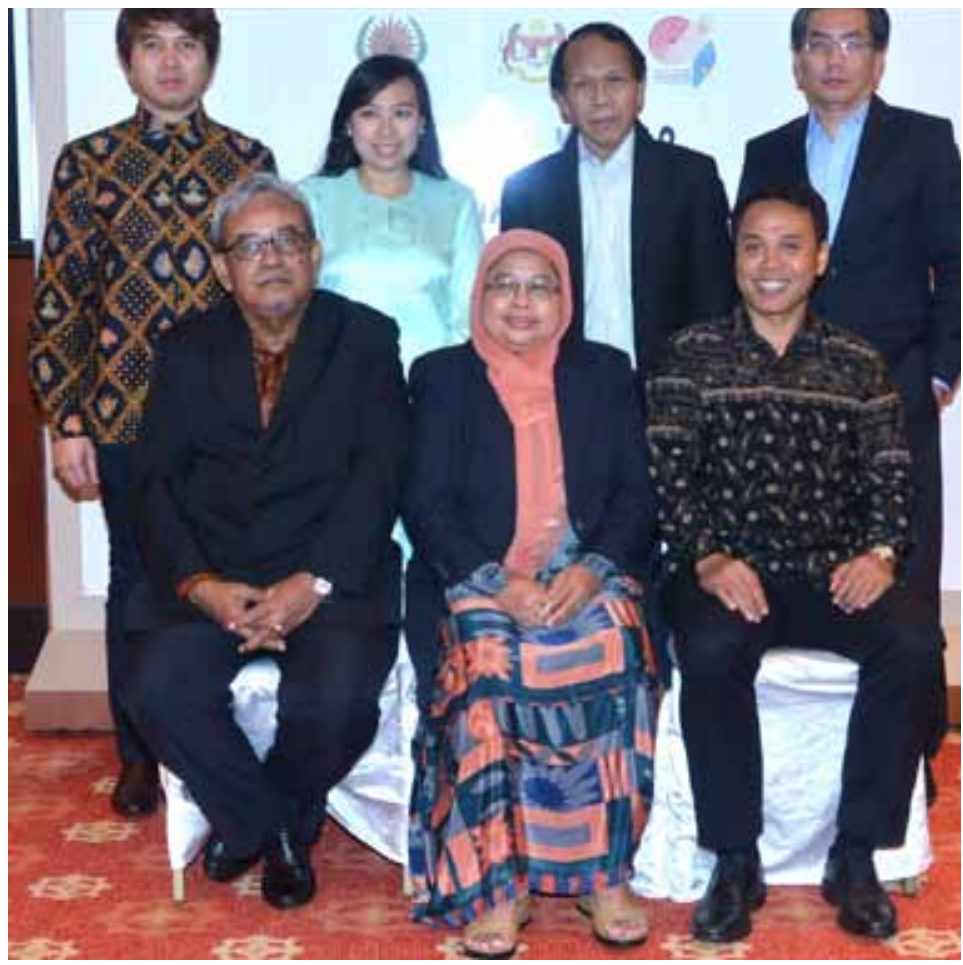

Figure 2 The Singapore Delegation to the 18th MASTERA Conference, 2012. 
Singapore delivered the Kuliah Sastera Bandingan MASTERA XVI in Kuala Lumpur, Bandar Seri Begawan and Jakarta. On 12 December 2013, he delivered the Kuliah Kesusasteraan Bandingan MASTERA entitled "Mendepani Budi Laksana, Menyanggahi Cita Bencana: Bacaan Geosastera dalam Sastera Melayu-Indonesia" at Universiti Sains Malaysia, Penang. The event was jointly organized by the Literature Department of the School of Humanities, Universiti Sains Malaysia and Dewan Bahasa dan Pustaka, Malaysia. In the context of the discussion and arguments forwarded in this article, the lecture titles of Dr. Azhar Ibrahim Alwee and Associate Professor Dr. Hadijah Rahmat are clear proof that Malay literature in Singapore and Malaysia (including Indonesia dan Brunei) are, in fact, still one!

Other than jump-starting MASTERA, Dewan Bahasa dan Pustaka has done the same with Majlis Bahasa Brunei-Indonesia-Malaysia (MABBIM), established in Jakarta on 29 December 1972 and reinforced on 4 November 1985 with the entry of Brunei. MABBIM is a regional language body established specifically to plan and review the development of the Malay/ Indonesian languages in Southeast Asia. There are three member nations, namely, Brunei, Indonesia, and Malaysia. Singapore is not yet a member, possibly because the status of the Malay language there is different from Brunei, Indonesia and Malaysia. However, Singapore frequently sends representatives to the MABBIM gatherings through Majlis Bahasa Melayu Singapura. Thus it has the opportunity to benefit widely from the body in matters related to the Malay language.

In this context, it should also be noted that the Singaporean Government has appointed Dewan Bahasa dan Pustaka as special consultant for affairs of Malay language and literature. In the north, the Thai Government too has requested advisory services from Dewan Bahasa dan Pustaka. In fact, these close relations have ultimately resulted in the establishment of Dewan Bahasa dan Pustaka Melayu in Patani by the Thai Government, solely for Thailand.

In publishing, it is worth mentioning that apart from Dewan Bahasa dan Pustaka, several private publishers in Malaysia have been cooperative in publishing works of Singaporean writers, especially established writers like Isa Kamari. These publishers include Al-Ameen Serve Holdings Sdn. Bhd which has published five of Isa Kamari's works, namely, Atas Nama Cinta: Novel Epik Sejarah (2006), 33 Puisi Tanah Suci (2006), Memeluk Gerhana (2007), Rawa: Tragedi Pulau Batu Putih (2009) and Duka Tuan Bertakhta (2011). Aside from that, Penerbit PTS too has published one of Isa Kamari's work, that is, Menara (2010). The publication of these works is not only a sign of the close relations between Singaporean authors and 
Malaysian publishers, but more than that, it helps to overcome issues of marketing works resulting from the dearth of a Malay audience in Singapore. As a matter of fact, Isa Kamari himself has been outspoken on the possibility that the future of Malay literature in Singapore is dependent upon Malaysian readers (Nurul Farina Nazlan, 2011).

Finally, from a perspective of unity among Malay literature in Singapore, Malaysia, and the whole Malay region, a very interesting and positive current development must be noted. This relates to the cooperation between young Malaysian and Singaporean authors in jointly publishing creative works. A clear example is the publication in 2010 of the book, Dari Jendela Zaman Ini /From the Window of this Epoch. The book was jointly published by the Malaysian Institute of Translation and Books and the National Arts Council of Singapore. It is a collection of 100 bilingual poems by 73 Malaysian and Singaporean poets. Another example is the publication of Melangkaui Jambatan Kedua: Cerpen terpilih dari Malaysia dan Singapura/Beyond the 2nd Link: Selected Short Fiction from Malaysia and Singapore, jointly edited by Rahimidin Zahari from Malaysia and Kartini Anwar from Singapura. This book of 12 short stories by 12 authors was also published jointly by the Malaysian Institute of Translation and Books and the National Arts Council of Singapore in 2012. Both the books mentioned were launched in Singapore during the Singapore Writers Festival. The latter title was launched on 4 November 2012 at the Festival Pavilion, Singapore Management University. In both cases, the cooperation has proliferated, that is, between the authors/ editors and between publishers from both countries. Such joint efforts could certainly increase the publication, distribution and sale of books because it would directly involve audiences in the two countries. Therefore, it is hoped that such joint efforts will be continued, and in fact increase, from time to time.

\section{CONCLUSION}

Before the separation in 1965, Malay literature in Singapore and Malaysia was always regarded as a shared entity. In fact, at the end of the colonial era, for a long time Singapore was a major centre of development for Malay literature. This was mainly due to the activities of Angkatan Sasterawan 50 authors, along with their friends in the newspaper and film industries, centred in Singapore at the time. Therefore, Singapore's withdrawal from Malaysia in 1965 brought traumatic changes to the status and development of the Malay language and literature in Singapore. 
This article has scrutinized developments in Singapore and Malaysia since 1965, particularly the efforts and activities implemented to guard against retardation in the context of post-1965 literature in Singapore, as well as fragmentation in the unity that existed in the literature of the two nations. In fact, the efforts undertaken were to ensure they would continue to develop as one literature although no longer existing in the same sosio-political ecosphere. Discussion has shown that despite the traumatic results of the separation, and the existence of two different socio-political ecospheres, activists of language and literature in Singapore have persisted diligently, and along with activists and institutions in Malaysia, continued to develop and enrich the single, shared Malay literature. This was due to the rise of early awareness which was immediately followed by introspection, strategic planning and action. All of this eventually succeeded in preserving and developing Malay literature in Singapore and Malaysia with results that have proliferated.

\section{REFERENCES}

Anuar Othman and Mana Sikana, 2003. Jatuh Ke Laut Menjadi Pulau: Pemikiran Sastera Malaysia \& Singapura.Singapore:Anuar Othman \& Associates Media Enterprise.

Anugerah Persuratan 2011: Kumpulan Karya dan Ulasan Juri, 2013. Singapore:

Darul Andalus Pte. Ltd.

Dari Jendela Zaman Ini / From the Window of this Epoch, 2010. Kuala Lumpur/

Singapore: ITBM \& National Arts Council, Singapore.

Hadijah Rahmat, 2000. Di Tengah Alam. Kuala Lumpur: Dewan Bahasa dan Pustaka. Hadijah Rahmat, 2005. Mengukir Air di Pesisir: Sastera Melayu Indonesia dalam Arus Jagat. Kuala Lumpur: Dewan Bahasa dan Pustaka.

http:/hardiaziqin.blogspot.com/2011/10/faktor-faktor-yang-mempengaruhi.html; accessed on 10 November 2013.

Isa Kamari, 1998. Satu Bumi. Singapore: Pustaka Melayu Publisher.

Isa Kamari, 2006. 33 Puisi Tanah Suci. Kuala Lumpur: Al-Ameen Serve Holdings Sdn. Bhd.

Isa Kamari, 2006. Atas Nama Cinta: Novel Epik Sejarah. Kuala Lumpur: Al-Ameen

Serve Holdings Sdn. Bhd.

Isa Kamari, 2007. Memeluk Gerhana. Kuala Lumpur: Al-Ameen Serve Holdings Sdn. Bhd.

Isa Kamari, 2009. Rawa: Tragedi Pulau Batu Putih. Kuala Lumpur: Al-Ameen Serve Holdings Sdn. Bhd. 
Isa Kamari, 2010. Menara. Kuala Lumpur: Al-Ameen Serve Holdings Sdn. Bhd. Isa Kamari, 2011. Duka Tuan Bertakhta. Kuala Lumpur: Al-Ameen Serve Holdings Sdn. Bhd.

Keris Mas, 1979. 30 Tahun Sekitar Sastera. Kuala Lumpur: Dewan Bahasa dan Pustaka.

Mohamed Pitchay Gani Bin Mohamed Abdul Aziz, 2005. Leksikon: Direktori

Penulis Melayu Singapura Pasca 1965. Singapore: Angkatan Sasterawan `50 and National Library Board, Singapore.

Nazmi Yaakub. "Ambil iktibar ASAS 50" in Berita Minggu, 30 November 2010.

Nizqin. "Kearah sastra yang beridentiti S'pura" in Berita Harian, 29 May 1977.

Nurul Farina Nazlan. "Sastera Melayu Singapura" in Berita Harian, 7 February 2011.

Padilah Haji Ali, Jamaludin Mohd. Sulong and Arshad Rawian (ed.), 2012. Meneliti Jejak, Membaharui Babak. Kuala Lumpur: Dewan Bahasa dan Pustaka.

Rahimidin Zahari and Kartini Anwar (ed.), 2012. Melangkaui Jambatan Kedua: Cerpen terpilih dari Malaysia \& Singapura/ Beyond the 2nd Link: Selected Short Fiction from Malaysia and Singapore. Kuala Lumpur/Singapore: ITBM \& National Arts Council, Singapore.

Rasiah Halil, 1991. Orang Luar. Kuala Lumpur: Dewan Bahasa dan Pustaka.

Rasiah Halil, 2013. Nyanyian Si Anak Dagang. Kuala Lumpur: Dewan Bahasa dan Pustaka.

Ravi Velod and Cheng Puay Koon, 2002. The Difference between Malaysians and Singaporeans. Singapore: NewsBooks.

Singapore Ministry of Culture, 1965. Separation: Singapore's Separation from the Federation of Malaysia 9th August, 1965. Singapore: Ministry of Culture.

"Singapura Anggota Terbaru MASTERA". Kosmo, 18 October, 2012.

Sumadi Sarkawi. "Ke mana matlamat cerpen2 hari ini” in Berita Harian, 25 June 1979. Ungku Maimunah Mohd. Tahir, 1987. Modern Malay Literary Culture: A Historical Perspective. Singapore: Institute of Southeast Asian Studies.

Vadaketh, Sudhir, 2012. Floating on a Malayan Breeze: Travels in Malaysia and Singapore. Singapore: National University of Singapore Press.

(Translated by Lalita Sinha) 